\title{
The Contribution of Social Media and Mobile Application to Individual Subjective Well-Being in Counseling Perspective
}

\author{
Zadrian Ardi ${ }^{1}$, Indah Sukmawati ${ }^{2}$ \\ ${ }^{1}$ Universitas Negeri Padang
}

\begin{tabular}{l} 
Article Info \\
\hline Article history: \\
Received Jan $19^{\text {th }}, 2018$ \\
Revised Sept $25^{\text {th }}, 2018$ \\
Accepted Jun $3^{\text {rd }}, 2019$ \\
\hline
\end{tabular}

\section{Keyword:}

Social media usage; Subjective well-being; Counselor role

\begin{abstract}
Various researches in information technology, especially in the era of industrial revolution 4.0 have revealed that there has been a major change in the use of wireless devices in the past decade. The high internet usage is directly proportional to the use of social media which is increasing every year. Social media in principle provides various communities in accordance with the purpose and development goals of the platform. This of course will arouse the arena of new problems at the client's life level, thus becoming a challenge for counselors in the era of industrial revolution 4.0. Counselors in this era are required to have a deeper understanding of the root causes that might arise from the online world. Counselors are also required to have special skills in handling individual welfare conditions related to the impact of activities on social media. This study discusses the general impact of social media on individual subjective well-being conditions. This study involved 174 respondents spread throughout the territory of Indonesia by its demography. The results showed that respondents needed mental health interventions through online channels and not in the form of social media.
\end{abstract}

(C) 2019 The Authors. Published by Redwhitepress.

This is an open access article under the CC BY-NC-SA license

(https://creativecommons.org/licenses/by-nc-sa/4.0/

\section{Corresponding Author:}

Indah Sukmawati,

Universitas Negeri Padang

Email: indahsukmawati@fip.unp.ac.id

\section{Introduction}

The development of technology that has now reached the stage of industrial revolution 4.0 is one of the advances made by humans in the 21st century (Ardi et al., 2018, 2019; Carley \& Spapens, 2017; Fitria et al., 2018; O'Neill et al., 2017; Romero, Usart, \& Ott, 2015; Sheikh, Sood, \& Bates, 2015). In the last decade, various branches of research and development have been carried out related to this technology. One of the most striking developments in information technology is the dynamics of the internet globally (Andreassen et al., 2016; Billieux, Maurage, Lopez-Fernandez, Kuss, \& Griffiths, 2015; Prestin, Vieux, \& Chou, 2015; Xiang, Wang, O'Leary, \& Fesenmaier, 2015). This rapid development has experienced a very significant increase since the launch of Web 2.0 in the early 2000s (Ardi et al., 2019; Ifdil et al., 2018; Ngai, Moon, Eric, \& Spencer, 2015).

Content and innovation on social media is a new era in the internet in recent years (Benkler, Roberts, Faris, Solow-Niederman, \& Etling, 2015; Lyytinen, Yoo, \& Boland Jr, 2016; Simula, Töllmen, \& Karjaluoto, 2015). Social media is a new area for internet usage that is targeted more by internet users around the world. This condition makes social media a platform that provides certain content on the internet with large capacity 
and continues to grow because of the very active interaction between users in it (Loeb, 2015; Pittman \& Reich, 2016; Seltzer, Jean, Kramer-Golinkoff, Asch, \& Merchant, 2015; Thoma et al., 2015).

Recent studies have shown that more than $86 \%$ of internet users in the United States, $79 \%$ of users from Europe are active accessers of social media with content that continues to evolve to adapt to existing topics in the world (Brooks, 2015). In addition, at least more than 2.3 billion people from all over the world are registered as active social media users. For Indonesia itself, there are more than 139 million active social media users who make up 87\% of internet users in Indonesia (Hasfi, Usman, \& Santosa, 2015), so that almost all internet users in Indonesia have social media accounts (Alwagait, Shahzad, \& Alim, 2015; Ceron, 2015; Obar \& Wildman, 2015). This figure proves that the strength of social media is something that cannot be underestimated and requires more attention by various parties.

Literally, the term social media is an activity carried out by many people in a particular period of time through internet-based technology, so that there is a connection between users and forming a particular community (Carley \& Spapens, 2017; Xiang et al., 2015). In many studies, social media development focuses on various behavioral activities of individuals involved in it, such as sharing personal influences, sharing personal info-info, sharing identities etc (Afdal et al., 2019; Zadrian Ardi \& Maizura, 2018; 2017; Ngai, Tao, \& Moon, 2015; Roth, Bobko, Van Iddekinge, \& Thatcher, 2016).

Most significant changes occur in the use of internet platforms in the world, which initially focused more on personal blogs, official websites and the like to be focused on social media with stronger data strength (Benkler et al., 2015; Carley \& Spapens, 2017; Prestin et al., 2015). Social media can build a new community, access the latest news shared by others on the same network platform or across platforms, share new knowledge, connect with new friends or cancel friendships in one community and many other things, including in personal business development, corporate and career development (Ding, Phang, \& Zhang, 2012; Ngai, Moon, et al., 2015). The delivery of personal and corporate information to stakeholders is very likely to be done through social media and even has been specifically built platforms according to their respective characteristics (Lyytinen et al., 2016; Seltzer et al., 2015; Thoma et al., 2015). So that this becomes its own strength for social media and its benefits to individuals in general.

\section{Methods}

This study involved 174 respondents from various cultural, educational, socio-economic backgrounds and basic insights. This study involved respondents spread across all regions in Indonesia with a demographic distribution of $25.85 \%$ men $74.14 \%$ women and $31.79 \%$ working, and the remaining $68.21 \%$ were unemployed. This study uses two instruments for measurement, which are Mental Health Inventory (MHI) (Al Mutair et al., 2018) which has been translated and adapted into Indonesian in a shortened version and has met the feasibility test and fulfills the requirements of a good instrument with Cronbach Alpha-KR20 value of 0.93. The next instrument uses the Acceptability of Mental-Health Mobile App Survey (AMMS) with Cronbach Alpha-KR20 value of 0.89. The data findings were analyzed by using Network Psychometrics analysis (Epskamp, Maris, Waldorp, \& Borsboom, 2016) and Rasch analysis (Sumintono \& Widhiarso, 2014).

\section{Result and Discussion}

Data analysis shows that the use of mobile applications in the form of social media and similar applications has a certain impact on individual mental health conditions. More specifically, some items in the research show that respondents tend to share their feelings and emotions through a platform to be heard by others. This condition can generally be seen in Figures 1 and 2 .

In Figures 1 and 2 it can be seen that there are groups of interconnected items. The green line indicates there is positive connectivity (positive relation) between the two factors, while the red line indicates the opposite. The MH code shows measurements regarding Mental Health, while A code shows the level of acceptance and use of mobile applications and social media related to well-being.

More specifically in Figure 1, there is a contradictory relationship between items MH14 and item A11, MH 14 contains the desire of individuals to end their lives and feel depressed, while item A11 contains the ability to be able to adapt to mobile-based applications in telling about the state of self own. This indicates that the process of good adaptation and the presence of a mobile-based application with the sharing method of information on self-condition can reduce a person's level of depression. This is certainly supported by a system that does not open up the possibility of mistaken interventions to the depressed state of individuals such as cyberbullying. While in Figure 2 it can be seen that the overall conditions of acceptance of the use of mobile and social media applications interact positively in supporting individual well-being conditions. Discussions about the findings of this model have been described previously (Z Ardi et al., 2018, 2019). 


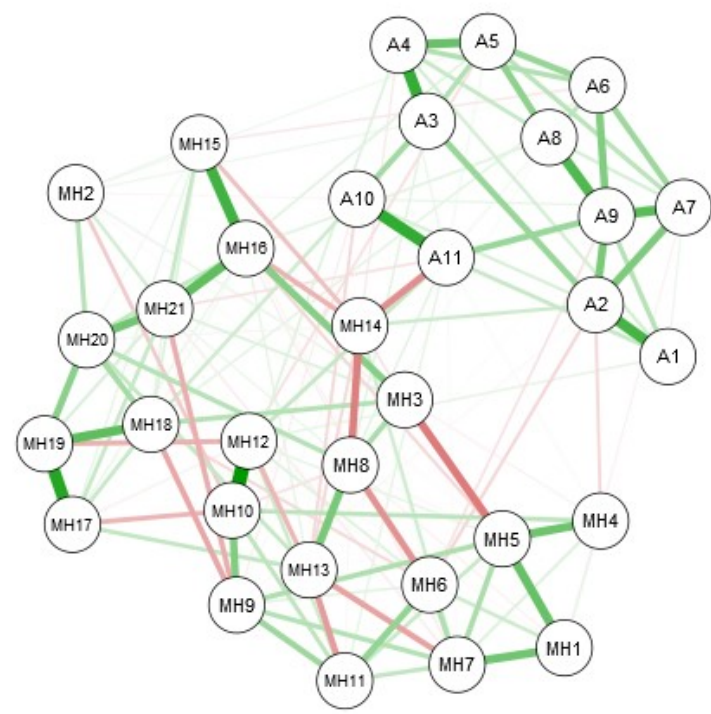

Figure 1. The interaction between mental health condition and acceptability intervention using mobile-app based on network model structure

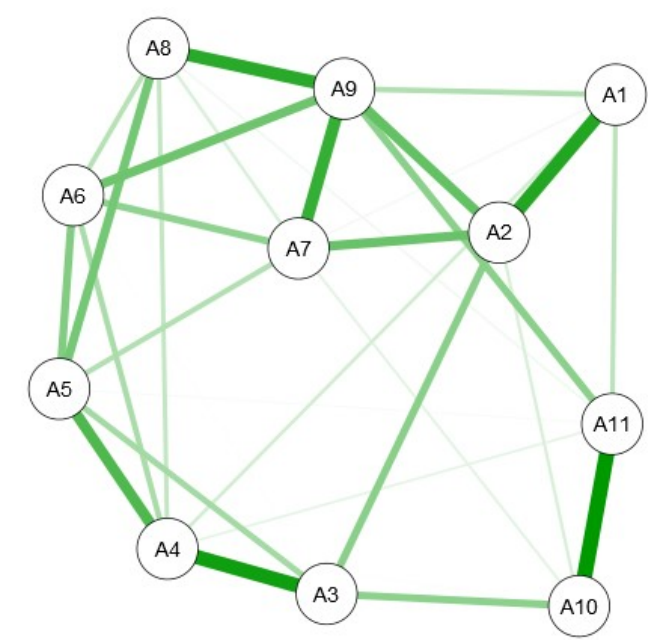

Figure 2. The acceptability of mental health intervention using mobile-app network model structure

\section{The internet and social media usage in the industrial revolution 4.0}

At the beginning of its development, social media was built on the basic assumption as a platform that served as an "Open Diary" in the late 1990s by Bruce and Susan Abelson (Machin-Mastromatteo, 2011; Mastromatteo, 2017). This development is intended so that other platform users can read diaries written by someone in the same community (Bosoteanu, 2013; Kohli \& Gupt, 2015). With the development of the internet that is very significant, so that the development of models and platforms also occur, so users who initially can only read, can provide comments, such as sharing advice and so on.

The current movement of the global economy is also one of them driven by the development of the internet (Castells, 2015; Poushter, 2016; Van Bergeijk, 2014), especially social media. For example, if it was difficult to give comments / testimonials to a product that was marketed, through social media such activities were very easy to occur, so that market dynamics would be more diverse (Leung, Law, Van Hoof, \& Buhalis, 2013; Luo, Zhang, \& Duan, 2013; Ngai, Tao, et al., 2015). In addition, social dynamics movements in the community also began to change from conventional community forums to online communities. Where individuals can make an open or secret association through social media (Bontcheva \& Rout, 2014; Dekker \& Engbersen, 2014; Hensby, 2017). Discussion of various things can be done through this media very effectively without having to meet and meet face to face.

In other words, social media can be said to be an internet-based application that allows users to exchange general and personal content (Brooks, 2015). Content on social media is very different from professional content available in the form of online newspapers, official sites and the like (Castells, 2015; Van Bergeijk, 2014). Content on social media depends on the creativity of users and is related to the personal lives of users.

\section{Social media and subjective well-being}

Social media is identified as having six basic functions, including the management of user identity, efforts to find experts on the internet, context awareness, content management, network awareness, and content exchange, six of which are based on the purpose of the internet community in sharing content and knowledge, and that also based on the need to stay connected with others through the internet network (Oh \& Syn, 2015).

This fact allows for changes in psychological conditions in individuals when making access to social media. To some extent, social media can generate positive reactions in individuals (Hudson, Roth, Madden, \& Hudson, 2015; Maier, Laumer, Eckhardt, \& Weitzel, 2015; Utz, Schultz, \& Glocka, 2013), such as feeling 
happy when His posts were responded to by others, gained important insights through content shared by others, met other individuals with similar interests, got new things to develop themselves, and other positive things. However, social media can also interfere with the daily conditions of individuals, especially conditions related to the psychological aspects of individuals (Maier et al., 2015).

Excessive use of social media can lead to conditions of addiction to the individual. Research shows that only $40 \%$ of employee time is used to focus on work. More than $28 \%$ of employee time is used up to use / access social media on the sidelines of work, and if employees have accessed the social media, it will take 25 minutes to refocus on their work (Brooks, 2015). Based on the results of the Cengage Learning survey (2014) revealed that more than $59 \%$ of students access social media when learning takes place, so that this results in a lack of focus on students participating in learning, lack of participation in discussion activities, lack of focus on assignments, and disruption of the transfer process in learning to students (Jin, Liu, \& Austin, 2014; Perloff, 2014; Uche \& Obiora, 2016).

Another addictive condition that affects the mental health of individuals, especially on subjective well being is dependence on activities and activities on social media. For example activities to post content, comments, share personal activities and so on. Individual mood changes because comments from social media will also affect the condition of well being (Best, Manktelow, \& Taylor, 2014; Sengupta \& Chaudhuri, 2014; Whittaker \& Kowalski, 2015). The desire to be noticed is also shown by users of social media, such as sharing personal stories with the public and hoping for the expected response from others (Naslund, Grande, Aschbrenner, \& Elwyn, 2014; Uche \& Obiora, 2016). So that it can be said that social media is a technology that has a positive and negative side so that if individuals have been at the level of addiction, it will affect the subjective well being conditions.

\section{Challenges of counselors in the millennial era}

Technological developments provide various facilities in the types of humanitarian services, including in the counseling service process (Zadrian Ardi, 2014; Zadrian Ardi, Ibrahim, \& Said, 2012; Restu, Yusri, \& Ardi, 2013). With the presence of the internet, counseling services can be offered through the network (online) to clients without having to meet face to face (face to face). Various client problems can also come from internet use and other things related to it, including in the use of social media (Cundy, 2014; Dowling \& Rickwood, 2013; Richards \& Viganó, 2013). Counselors as educators and social workers have their own challenges in providing services, especially in the millennium with the goal of digital generation services (digital native).

The challenge of the counselor can be maladjusment conditions that arise from excessive internet use, social problems originating from the internet, as well as other addictions that arise (Karvinen et al., 2017; Whittaker \& Kowalski, 2015). Another case that can arise is the rampant cyberbullying behavior on various social media platforms so that further effects emerge which can harm individuals and those around them. These facts require counselors to be responsive to the development of information technology and various cases that arise because of this technology. In addition, counselors are also expected to have various insights, knowledge, values and attitudes that can be used as appropriate references in handling clients with cases relating to the influence of information technology (Ardi, Z., 2017).

\section{Conclusion}

The innovation and development of information technology has opened up opportunities for the growth of various social media platforms in the world (Ruths \& Pfeffer, 2014). Social media is a new world that is mostly aimed at by various users in the world to share certain content and interact with each other so as to form a digital community (Bonilla \& Rosa, 2015; Habibi, Laroche, \& Richard, 2014). To some extent, social media can create positive reactions in individuals, such as gaining important insights through content shared by others, meeting other individuals with similar interests, getting new things to develop themselves, and other positive things. However, social media can also interfere with the daily conditions of individuals, especially conditions related to the psychological aspects of individuals (Ardi, Z. \& Erlamsyah, 2017; Ardi, Z., Viola, \& Sukmawati, 2018; Ardi, Z. \& Yendi, 2017). Various problems that arise from social media require counselors to be responsive to the development of information technology are expected to have various insights, knowledge, values and attitudes that can be used as an appropriate reference in handling clients with cases relating to the influence of information technology.

\section{Acknowledgement}

This article was first published at the International Counseling Seminar in 2017 with the theme "The Responsibility of Counselor and Education in Millennium Era" and republished with various changes and the addition of theoretical studies, especially in novelty and reference aspects. 
The Contribution of Social Media and Mobile Application to Individual Subjective Well-Being in Counseling Perspective

\section{References}

Afdal, A., Alizamar, A., Ifdil, I., Ardi, Z., Sukmawati, I., Zikra, Z., ... Hariyani, H. (2019). An Analysis of Phubbing Behaviour: Preliminary research from counseling perspective. In International Conference on Educational Sciences and Teacher Profession (ICETeP 2018). Atlantis Press.

Al Mutair, A., Al Mohaini, M., Fernandez, R., Moxham, L., Lapkin, S., \& Ham $\square$ Baloyi, W. ten. (2018). Psychometric testing of the mental health inventory in an Arabian context: Cross $\square$ cultural validation study. Nursing Open.

Alwagait, E., Shahzad, B., \& Alim, S. (2015). Impact of social media usage on students academic performance in Saudi Arabia. Computers in Human Behavior, 51, 1092-1097. Retrieved from http://www.sciencedirect.com/science/article/pii/S0747563214004804

Andreassen, C. S., Billieux, J., Griffiths, M. D., Kuss, D. J., Demetrovics, Z., Mazzoni, E., \& Pallesen, S. ale. (2016). The relationship between addictive use of social media and video games and symptoms of psychiatric disorders: A large-scale cross-sectional study. Psychology of Addictive Behaviors, 30(2), 252. Retrieved from http://irep.ntu.ac.uk/id/eprint/27290/7/27290_Kuss.pdf

Ardi, Z. (2014). Cita-cita Perkerjaan dan Pilihan Peminatan Siswa Sekolah Menengah Atas Negeri di Sumatera Barat.

Ardi, Z., \& Erlamsyah, E. (2017). Peningkatan Kualitas Penulisan Artikel Ilmiah bagi Kepala Sekolah. Jurnal Aplikasi IPTEK Indonesia, 1(1), 25-34. Retrieved from http://bk.ppj.unp.ac.id/index.php/aiptekin/article/download/4/3

Ardi, Z., Ibrahim, Y., \& Said, A. (2012). Capaian Tugas Perkembangan Sosial Siswa dengan Kelompok Teman Sebaya dan Implikasinya terhadap Program Pelayanan Bimbingan dan Konseling. Konselor.

Ardi, Z., \& Maizura, N. (2018). The Psychological Analysis of Divorce at Early Marriage. International Journal of Research in Counseling and Education, 1(3), 27-32.

Ardi, Z., Putra, M. R. M., \& Ifdil, I. (2017). Ethics And Legal Issues In Online Counseling Services: Counseling Principles Analysis. Jurnal Psikologi Pendidikan Dan Konseling: Jurnal Kajian Psikologi Pendidikan Dan Bimbingan Konseling, 15-22.

Ardi, Z., Rangka, I. B., Ifdil, I., Suranata, K., Azhar, Z., Daharnis, D., ... Alizamar, A. (2019). Exploring the elementary students learning difficulties risks on mathematics based on students mathematic anxiety, mathematics self-efficacy and value beliefs using rasch measurement. In Journal of Physics: Conference Series (Vol. 1157, p. 32095). IOP Publishing.

Ardi, Z., Sukmawati, I., Ifdil, I., Afdal, A., Rangka, I. B., \& Suranata, K. (2018). Exploring the acceptability of internet-based mental health mobile app services using network psychometrics analysis. In Journal of Physics: Conference Series (Vol. 1114, p. 12106). IOP Publishing.

Ardi, Z., Viola, K., \& Sukmawati, I. (2018). An Analysis of Internet Abuses Impact on Children's Moral Development. JPPI (Jurnal Penelitian Pendidikan Indonesia), 4(1), 44-50. Retrieved from http://jurnal.iicet.org/index.php/jppi/article/view/192

Ardi, Z., \& Yendi, F. M. (2017). Students Attitude Towards LGBTQ; the Future Counselor Challenges. Jurnal Konseling Dan Pendidikan, 5(2), Retrieved 74-79. http://jurnal.konselingindonesia.com/index.php/jkp/article/viewFile/181/161

Benkler, Y., Roberts, H., Faris, R., Solow-Niederman, A., \& Etling, B. (2015). Social mobilization and the networked public sphere: Mapping the SOPA-PIPA debate. Political Communication, 32(4), $594-624$. Retrieved

from https://cyber.harvard.edu/sites/cyber.law.harvard.edu/files/MediaCloud_Social_Mobilization_and_th e_Networked_Public_Sphere_0.pdf

Best, P., Manktelow, R., \& Taylor, B. (2014). Online communication, social media and adolescent wellbeing: A systematic narrative review. Children and Youth Services Review, 41, 27-36. Retrieved from http://www.sciencedirect.com/science/article/pii/S0190740914000693

Billieux, J., Maurage, P., Lopez-Fernandez, O., Kuss, D. J., \& Griffiths, M. D. (2015). Can disordered mobile phone use be considered a behavioral addiction? An update on current evidence and a comprehensive 
model for future research. Current Addiction Reports, 2(2), 156-162. Retrieved from https://link.springer.com/article/10.1007/s40429-015-0054-y

Bonilla, Y., \& Rosa, J. (2015). \# Ferguson: Digital protest, hashtag ethnography, and the racial politics of social media in the United States. American Ethnologist, 42(1), 4-17. Retrieved from http://blogs.umass.edu/jdrosa/files/2015/01/Bonilla-Rosa-2015-Ferguson.pdf

Bontcheva, K., \& Rout, D. (2014). Making sense of social media streams through semantics: a survey. Semantic Web, 5(5), 373-403. Retrieved from http://ai2-s2pdfs.s3.amazonaws.com/d659/0674fe5fb16cf93c9ead436555d4d984d870.pdf

Bosoteanu, I. C. (2013). Impactul social media asupra comunicarii politice. Sociologie Romaneasca, $11(1), 8$. Retrieved from https://search.proquest.com/openview/7a0f0b70198a05e7257108656d86384e/1?pqorigsite $=$ gscholar\&cbl $=626463$

Brooks, S. (2015). Computers in Human Behavior Does personal social media usage affect efficiency and wellbeing $\square$ ? Computers in Human Behavior, 46, 26-37. https://doi.org/10.1016/j.chb.2014.12.053

Carley, M., \& Spapens, P. (2017). Sharing the world: sustainable living and global equity in the 21st century. Routledge. Retrieved

from https://books.google.co.id/books?hl=en\&lr=\&id=Oh03DwAAQBAJ\&oi=fnd\&pg=PT14\&dq=informat ion+technology+is+the+progress+achieved +21 st+century\&ots=PKotRdqUzT\&sig=DYauUonfVfpBIZCCmgrIn8YFw8\&redir_esc $=\mathrm{y} \# \mathrm{v}=$ onepage $\& \mathrm{q} \& \mathrm{f}=$ false

Castells, M. (2015). Networks of outrage and hope: Social movements in the Internet age. John Wiley \& Sons. Retrieved

from https://books.google.co.id/books?hl=en\&lr=\&id=MzDOCQAAQBAJ\&oi=fnd\&pg=PR3\&dq=global+ economic+movement+due+to+the+internet\&ots=BZ1vhSfBZv\&sig=Dw77UKRWkEuqyUYeBeAB0hiRNE\&redir_esc $=\mathrm{y} \# \mathrm{v}=$ onepage $\& \mathrm{q}=$ global economic movement due to the internet $\& \mathrm{f}=$ false

Ceron, A. (2015). Internet, news, and political trust: The difference between social media and online media outlets. Journal of Computer-Mediated Communication, 20(5), 487-503. Retrieved from http://onlinelibrary.wiley.com/doi/10.1111/jcc4.12129/full

Cundy, L. (2014). Love in the Age of the Internet: Attachment in the Digital Era. Karnac Books. Retrieved from https://books.google.co.id/books?hl=en\&lr=\&id=xWdRBQAAQBAJ\&oi=fnd\&pg=PR7\&dq=counseli ng+in+digital+era\&ots=rrdpmEnfxx\&sig=JTcWxUExQlaCPZ9QlivhAQptHIo\&redir_esc=y\#v=onepa ge\&q\&f=false

Dekker, R., \& Engbersen, G. (2014). How social media transform migrant networks and facilitate migration. Global Networks, 14(4), 401-418. Retrieved from http://www.godfriedengbersen.com/wpcontent/uploads/Working-Paper-IMI-Dekker-Engbersen.pdf

Ding, Y., Phang, C. W., \& Zhang, C. (2012). The Influence Of User Interaction And Participation In Social Media On The Consumption Intention Of Niche Products.

Dowling, M., \& Rickwood, D. (2013). Online Counseling and Therapy for Mental Health Problems: A Systematic Review of Individual Synchronous Interventions Using Chat. Journal of Technology in Human Services, 31(1), 1-21. https://doi.org/10.1080/15228835.2012.728508

Epskamp, S., Maris, G. K. J., Waldorp, L. J., \& Borsboom, D. (2016). Network psychometrics. ArXiv Preprint ArXiv:1609.02818.

Fitria, L., Ifdil, I., Erwinda, L., Ardi, Z., Afdal, A., Sari, A. P., ... Churnia, E. (2018). Exploring internet addiction on adolescents. In 2018 Workshop on Multidisciplinary and Its Applications: Applied Mathematics, Computer Science, Information Systems, and Information Technology, WMA-Mathcomtech 2018 (Vol. 1114). Universitas Putra Indonesia YPTK, Padang, Indonesia: Institute of Physics Publishing. https://doi.org/10.1088/1742-6596/1114/1/012076

Habibi, M. R., Laroche, M., \& Richard, M.-O. (2014). The roles of brand community and community engagement in building brand trust on social media. Computers in Human Behavior, 37, 152-161. Retrieved from https://pdfs.semanticscholar.org/85b4/b9a977e64c12e0bdea0952667900e93d9e58.pdf

Hasfi, N., Usman, S., \& Santosa, H. P. (2015). Refleksi Peran Media Sosial dalam Demokrasi dan Pemilu di Berbagai Negara: Bagaimana dengan Perannya dalam Proses Demokratisasi di Indonesia? Komunikasi Massa Jurnal, 8(2), 203. 
The Contribution of Social Media and Mobile Application to Individual Subjective Well-Being in Counseling Perspective

Hensby, A. (2017). Open networks and secret Facebook groups: exploring cycle effects on activists' social media use in the 2010/11 UK student protests. Social Movement Studies, 16(4), 466-478. Retrieved from http://www.tandfonline.com/doi/full/10.1080/14742837.2016.1201421

Hubungan antara Kecemasan dalam Belajar dengan Motivasi Belajar Siswa. (2013). Konselor.

Hudson, S., Roth, M. S., Madden, T. J., \& Hudson, R. (2015). The effects of social media on emotions, brand relationship quality, and word of mouth: An empirical study of music festival attendees. Tourism Management, 47, 68-76. Retrieved from http://course.festivals.coplacdigital.org/wpcontent/uploads/2016/01/hudson.pdf

Ifdil, I., Putri, Y. E., Fadli, R. P., Erwinda, L., Suranata, K., Ardi, Z., ... Rangka, I. B. (2018). Measuring internet addiction: Comparative studies based on gender using Bayesian analysis. In 2018 Workshop on Multidisciplinary and Its Applications: Applied Mathematics, Computer Science, Information Systems, and Information Technology, WMA-Mathcomtech 2018 (Vol. 1114). Universitas Negeri Padang, Padang, Indonesia: Institute of Physics Publishing. https://doi.org/10.1088/1742-6596/1114/1/012073

Jin, Y., Liu, B. F., \& Austin, L. L. (2014). Examining the role of social media in effective crisis management: The effects of crisis origin, information form, and source on publics' crisis responses. Communication Research, 41(1), 74-94. Retrieved from https://www.researchgate.net/profile/Brooke_Liu/publication/274985420_Examining_the_Role_of_S ocial_Media_in_Effective_Crisis_Management_The_Effects_of_Crisis_Origin_Information_Form_and_ Source_on_Publics\%27_Crisis_Responses/links/5790fff408ae64311c11a3af/

Karvinen, K. H., Balneaves, L., Courneya, K. S., Perry, B., Truant, T., \& Vallance, J. (2017). Evaluation of Online Learning Modules for Improving Physical Activity Counseling Skills, Practices, and Knowledge of Oncology Nurses. (Vol. 44, p. 729). Retrieved from https://www.ncbi.nlm.nih.gov/pubmed/29052662

Kohli, S., \& Gupt, A. (2015). Identification of Human Behavioral Traits Using Social Media. Retrieved from http://infonomics-society.org/wp-content/uploads/ijmip/published-papers/volume-5-

2015/Identification-of-Human-Behavioral-Traits-Using-Social-Media.pdf

Leung, D., Law, R., Van Hoof, H., \& Buhalis, D. (2013). Social media in tourism and hospitality: A literature review. Journal of Travel \& Tourism Marketing, 30(1-2), 3-22. Retrieved from http://www.tandfonline.com/doi/abs/10.1080/10548408.2013.750919

Loeb, S. (2015). Social media makes global urology meetings truly global. BJU International, $115(2), 175$. Retrieved from http://onlinelibrary.wiley.com/doi/10.1111/bju.13027/full

Luo, X., Zhang, J., \& Duan, W. (2013). Social media and firm equity value. Information Systems Research, 24(1), 146-163. Retrieved from http://www.fox.temple.edu/cms/wp-content/uploads/2013/09/SocialMedia-and-Firm-Equity-Value.pdf

Lyytinen, K., Yoo, Y., \& Boland Jr, R. J. (2016). Digital product innovation within four classes of innovation networks. Information Systems Journal, 26(1), 47-75. Retrieved from http://onlinelibrary.wiley.com/doi/10.1111/isj.12093/full

Machin-Mastromatteo, J.-D. (2011). Studying the Influence (or Mutual Shaping) of Social Networks in a Learning Experience: Methods for a Pilot Study. Retrieved from http://eprints.rclis.org/15987/1/qqm12011_machin.pdf

Maier, C., Laumer, S., Eckhardt, A., \& Weitzel, T. (2015). Giving too much social support: social overload on social networking sites. European Journal of Information Systems, 24(5), 447-464. Retrieved from https://link.springer.com/article/10.1057/ejis.2014.3

Mastromatteo, J. D. M. (2017). The Mutual Shaping of Social Networks, Learning Experiences, and Literacies: The Methods Revisited. Qualitative and Quantitative Methods in Libraries, 2(2), $195-205$. Retrieved from http://qqml-journal.net/index.php/qqml/article/download/94/84

Naslund, J. A., Grande, S. W., Aschbrenner, K. A., \& Elwyn, G. (2014). Naturally occurring peer support through social media: the experiences of individuals with severe mental illness using YouTube. PLOS One, 9(10), e110171. Retrieved from http://journals.plos.org/plosone/article?id=10.1371/journal.pone.0110171

Ngai, E. W. T., Moon, K. K., Eric, S. S. L., \& Spencer, S. K. C. (2015). Social media models, technologies , 
and applications. https://doi.org/10.1108/IMDS-03-2015-0075

Ngai, E. W. T., Tao, S. S. C., \& Moon, K. K. L. (2015). Social media research: Theories, constructs, and conceptual frameworks. International Journal of Information Management, 35(1), 33-44. Retrieved from http://www.sciencedirect.com/science/article/pii/S026840121400098X

O’Neill, B. C., Kriegler, E., Ebi, K. L., Kemp-Benedict, E., Riahi, K., Rothman, D. S., ... Kok, K. (2017). The roads ahead: narratives for shared socioeconomic pathways describing world futures in the 21st century. Global Environmental Change, 42, 169-180. Retrieved from http://www.pardee.du.edu/sites/default/files/O'Neill et al 2015 - The Roads Ahead.pdf

Obar, J. A., \& Wildman, S. S. (2015). Social media definition and the governance challenge: An introduction to the special issue. Retrieved from https://papers.ssrn.com/sol3/papers.cfm?abstract_id=2647377

Oh, S., \& Syn, S. Y. (2015). Motivations for Sharing Information and Social Support in Social Media : A Comparative Analysis of Facebook, Twitter, Delicious, YouTube, and Flickr. JOURNAL OF THE ASSOCIATION FOR INFORMATION SCIENCE AND TECHNOLOGY, 66(April), 2045-2060. https://doi.org/10.1002/asi

Perloff, R. M. (2014). Social media effects on young women's body image concerns: Theoretical perspectives and an agenda for research. Sex Roles, 71(11-12), 363-377. Retrieved from https://is.muni.cz/el/1423/podzim2014/PSY221P121/um/Perloff2014.SocialMediaEffectsBodyImage .BID.pdf

Pittman, M., \& Reich, B. (2016). Social media and loneliness: Why an Instagram picture may be worth more than a thousand Twitter words. Computers in Human Behavior, 62, 155-167. Retrieved from http://charsoomarketing.com/wp-content/uploads/2016/05/10.1016_j.chb_.2016.03.084-Socialmedia-and-loneliness-Why-an-Instagram-picture-may-be-worth-more-than-a-thousand-Twitter-words.pdf

Poushter, J. (2016). Smartphone ownership and internet usage continues to climb in emerging economies. Pew Research Center, 22. Retrieved from http://s1.pulso.cl/wp-content/uploads/2016/02/2258581.pdf

Prestin, A., Vieux, S. N., \& Chou, W. S. (2015). Is online health activity alive and well or flatlining? Findings from 10 years of the Health Information National Trends Survey. Journal of Health Communication, 20(7), 790-798. Retrieved from http://www.tandfonline.com/doi/full/10.1080/10810730.2015.1018590

Restu, Y., Yusri, Y., \& Ardi, Z. (2013). Studi Tentang Perilaku Agresif Siswa di Sekolah. Konselor, 2(1).

Richards, D., \& Viganó, N. (2013). Online counseling: A narrative and critical review of the literature. Journal of Clinical Psychology, 69(9), 994-1011.

Romero, M., Usart, M., \& Ott, M. (2015). Can serious games contribute to developing and sustaining 21st century skills? Games and Culture, 10(2), 148-177. Retrieved from https://www.researchgate.net/profile/Margarida_ROMERO/publication/272818467_Can_Serious_Ga mes_Contribute_to_Developing_and_Sustaining_21stCentury_Skills/links/54ef760f0cf25f74d7226890.pdf

Roth, P. L., Bobko, P., Van Iddekinge, C. H., \& Thatcher, J. B. (2016). Social media in employee-selectionrelated decisions: A research agenda for uncharted territory. Journal of Management, 42(1), 269-298. Retrieved from http://journals.sagepub.com/doi/full/10.1177/0149206313503018

Ruths, D., \& Pfeffer, J. (2014). Social media for large studies of behavior. Science, 346(6213), 1063-1064. Retrieved from http://science.sciencemag.org/content/346/6213/1063

Seltzer, E. K., Jean, N. S., Kramer-Golinkoff, E., Asch, D. A., \& Merchant, R. M. (2015). The content of social media's shared images about Ebola: a retrospective study. Public Health, 129(9), 1273-1277. Retrieved from http://www.sciencedirect.com/science/article/pii/S0033350615002851

Sengupta, A., \& Chaudhuri, A. (2014). Simply having a social media profile does not make teens more likely to be bullied online. Demographics and online behavior play a larger role. LSE American Politics and Policy. Retrieved from http://eprints.lse.ac.uk/59847/1/USAPP_Blog_Simply_having_a_social_media_profile_Sengupta\%26 Chaudhuri.pdf

Sheikh, A., Sood, H. S., \& Bates, D. W. (2015). Leveraging health information technology to achieve the "triple aim" of healthcare reform. Journal of the American Medical Informatics Association, 22(4), 849-856. Retrieved from https://academic.oup.com/jamia/article/22/4/849/1746364 
The Contribution of Social Media and Mobile Application to Individual Subjective Well-Being in Counseling Perspective

Simula, H., Töllmen, A., \& Karjaluoto, H. (2015). Facilitating innovations and value co-creation in industrial B2B firms by combining digital marketing, social media and crowdsourcing. In Marketing Dynamism \& Sustainability: Things Change, Things Stay the Same... (pp. 254-263). Springer. Retrieved from http://link.springer.com/chapter/10.1007/978-3-319-10912-1_84

Students Attitude Towards LGBTQ; the Future Counselor Challenges. (2017). Jurnal Konseling Dan Pendidikan.

Sumintono, B., \& Widhiarso, W. (2014). Aplikasi model Rasch untuk penelitian ilmu-ilmu sosial (edisi revisi). Trim Komunikata Publishing House.

Thoma, B., Sanders, J. L., Lin, M., Paterson, Q. S., Steeg, J., \& Chan, T. M. (2015). The social media index: measuring the impact of emergency medicine and critical care websites. Western Journal of Emergency Medicine, 16(2), 242. Retrieved from https://www.ncbi.nlm.nih.gov/pmc/articles/PMC4380373/

Uche, A. O., \& Obiora, A. V. (2016). Social Media Typology, Usage and Effects on Students of Nigerian Tertiary Institutions. International Journal of Innovative Research and Development, 5(8). Retrieved from http://www.ijird.com/index.php/ijird/article/download/98137/71300

Utz, S., Schultz, F., \& Glocka, S. (2013). Crisis communication online: How medium, crisis type and emotions affected public reactions in the Fukushima Daiichi nuclear disaster. Public Relations Review, 39(1), 40-46. Retrieved from http://www.sciencedirect.com/science/article/pii/S0363811112001816

Van Bergeijk, P. A. (2014). Economic diplomacy and the geography of international trade. Edward Elgar Publishing.

Whittaker, E., \& Kowalski, R. M. (2015). Cyberbullying via social media. Journal of School Violence, 14(1), 1129. Retrieved from http://www.tandfonline.com/doi/abs/10.1080/15388220.2014.949377

Xiang, Z., Wang, D., O'Leary, J. T., \& Fesenmaier, D. R. (2015). Adapting to the internet: trends in travelers' use of the web for trip planning. Journal of Travel Research, 54(4), 511-527. Retrieved from https://www.researchgate.net/profile/Zheng_Xiang5/publication/263161234_Adapting_to_the_Intern et_Trends_in_Travelers'_Use_of_the_Web_for_Trip_Planning/links/02e7e53a58331f410e000000/Adap ting-to-the-Internet-Trends-in-Travelers-Use-of-the-Web-for-Trip-Plan 